NBER WORKING PAPER SERIES

\title{
RETURNS TO APPRENTICESHIP TRAINING IN AUSTRIA: EVIDENCE FROM FAILED FIRMS
}

\author{
Josef Fersterer \\ Jörn-Steffen Pischke \\ Rudolf Winter-Ebmer \\ Working Paper 13344 \\ http://www.nber.org/papers/w13344
}

\author{
NATIONAL BUREAU OF ECONOMIC RESEARCH \\ 1050 Massachusetts Avenue \\ Cambridge, MA 02138 \\ August 2007
}

We thank Josh Angrist, Larry Katz, and participants at various seminars for helpful comments. We thank the Economic and Social Research Council (RES 000-22-01-0160) and the Austrian Science Fund (FWF-P-15422-G05) for financial support; and Pischke thanks the NBER for their hospitality. The views expressed herein are those of the author(s) and do not necessarily reflect the views of the National Bureau of Economic Research.

(C) 2007 by Josef Fersterer, Jörn-Steffen Pischke, and Rudolf Winter-Ebmer. All rights reserved. Short sections of text, not to exceed two paragraphs, may be quoted without explicit permission provided that full credit, including $\odot$ notice, is given to the source. 
Returns to Apprenticeship Training in Austria: Evidence from Failed Firms

Josef Fersterer, Jörn-Steffen Pischke, and Rudolf Winter-Ebmer

NBER Working Paper No. 13344

August 2007

JEL No. J24,J31

\begin{abstract} or larger than the OLS returns in our sample, indicating relatively little selection.

Josef Fersterer

Landesstatistischer Dienst Salzburg

Fanny-von-Lehnert-Strasse 1

5010 Salzburg

Austria

josef.fersterer@salzburg.gv.at

Jörn-Steffen Pischke

CEP

London School of Economics

Houghton Street

London WC2A 2AE

UK

and NBER

s.pischke@1se.ac.uk

Rudolf Winter-Ebmer

Department of Economics

University of Linz

Altenberger Strasse 69

4040 Linz-Auhof

Austria

rudolf.winterebmer@jku.at
\end{abstract}

Little is known about the payoffs to apprenticeship training in the German speaking countries for the participants. OLS estimates suggest that the returns are similar to those of other types of schooling. However, there is a lot of heterogeneity in the types of apprenticeships offered, and institutional descriptions suggest that there might be an important element of selection in who obtains an apprenticeship, and what type. In order to overcome the resulting ability bias we estimate returns to apprenticeship training for apprentices in failed firms in Austria. When a firm fails, current apprentices cannot complete their training in this firm. Because apprentices will be at different stages in their apprenticeship at that time, the failure of a firm will manipulate the length of the apprenticeship period completed for some apprentices. The time to the firm failure therefore serves as an instrument for the length of the apprenticeship completed both at the original firm and at other firms. We find instrumental variables returns which are similar 
There is substantial interest in the functioning of the apprenticeship training system in German speaking countries, which is often regarded as a potential model for other countries (Steedman, 2001; Heckman, 1993). The importance of skills is increasing even at the bottom end of the skill distribution, and apprenticeships are seen as one way to create high skill levels for non-college bound youths (Nickell and Bell, 1996, and Freeman and Schettkat, 2001, provide evidence for comparatively high skill levels at the bottom end of the German skill distribution). The apprenticeship systems in Germany, Austria and Switzerland are also believed to deliver relatively low youth unemployment rates because they facilitate an orderly school-to-work transition (OECD 1998, Ryan, 2001, Büchtemann, Schupp and Soloff, 1994).

The apprenticeship system is not just regarded as exemplary because of its role in the overall economy but also because it delivers desirable results for those who participate: a well paying, interesting job, adequate job security, and possibilities for advancement. This suggests that the private returns to such training must be high. While the benefits of the apprenticeship system are often alleged, there are few existing studies of the returns to apprenticeship training. Krueger and Pischke (1995) and Winkelmann (1996) present OLS estimates of the returns to apprenticeship training in Germany in the order of 15 to 20 percent, and Fersterer and Winter-Ebmer (2003a) find returns of 15 percent for Austria - as return to a training period of three to four years.

Estimating the returns to apprenticeship training is not straightforward. Soskice (1994) argues that there is a lot of heterogeneity in the quality of apprenticeships, and firms select apprenticeship candidates extensively among secondary school leavers. This selection would bias any OLS estimates of the returns to training but there is virtually no empirical evidence on the degree of selection. Much of the heterogeneity identified by Soskice is due to firm size, and the wages for apprenticeship-trained workers indeed increases strongly in the size of the training firm (see, for example, Acemoglu and Pischke, 1998 or Franz et al., 2000, for results on Germany). 
In this paper, we try to obtain estimates of the return to apprenticeship training, which are free from this selection bias. In order to overcome the selection, we will focus on failed firms. When a firm fails, current apprentices cannot complete their training in this firm. Because apprentices will be at different stages in their apprenticeship at that time, the failure of a firm will manipulate the length of the apprenticeship period completed for some apprentices, as long as not all of them complete the apprenticeship elsewhere after their firm fails. The time from entering a failing firm to the actual exit of the firm therefore serves as an instrument for the length of the apprenticeship completed both at the original firm and at other firms.

The empirical work is based on the universe of social security records for Austria from 1975 to 1998. This allows us to identify a large number of apprentices in failing firms. The comparisons we make are limited to apprentices in failing firms, because these firms will be different from firms that continue. Moreover, all the apprentices analyzed will have to find new employment during or soon after their apprenticeship.

Our analysis of the data suggests that apprentices are typically hired every year until the eventual closure of the firm. The maintained assumption in the identification of the returns is therefore that apprentices hired about one to four years before a firm fails will be very similar. We believe that this assumption is most defensible in firms where the failure is rather sudden. We therefore limit the analysis to small firms. We also exclude firms where much of the decline in employment occurs already before the eventual firm exit. We find instrumental variables estimates of the returns to training between 2 and 4 percent per year, which are similar or above our OLS estimates. These estimates tend to be towards the low end of the existing estimates for Austria.

No previous instrumental variables studies of the returns to apprenticeship training exist so far. A specific instrument typically picks out variation in a particular range of the endogenous variable. The only existing IV studies of the returns to schooling for Austria by Ichino and Winter-Ebmer (2004) and Fersterer and Winter-Ebmer (2003b) focus on secondary schooling. In Austria, differences in secondary schooling eventually tend to imply that an individual either obtains lower secondary schooling plus an apprenticeship or other vocational training, or a higher secondary degree plus academic education. This is not the relevant return for the marginal apprentice (i.e. someone at the 
borderline between undertaking an apprenticeship or no post-junior-high-school training at all). The same is true for IV studies of the returns to schooling in Germany by Ichino and Winter-Ebmer (1999, 2004) and Becker and Siebern-Thomas (2004).

The remainder of this paper is organized as follows. The next section describes the Austrian schooling and training system. Section 3 describes the data set we use. The following section discusses the estimation strategy and section 5 presents the results. Section 6 offers some concluding remarks.

\section{The Austrian Schooling and Training System}

The Austrian school system tends to be relatively complex, with a multitude of different educational routes at a particular age. Figure 1 presents a schematic representation of the system. Children start school at age six and attend a four-year primary school. After grade four, the school system tracks students into two types of secondary schools. Academic secondary schools lead to a university entrance exam (Matura) after grade 12. School leavers from this type of school typically enter universities, polytechnics (Fachhochschule), or other tertiary academies. General secondary school (Hauptschule) lasts for 4 years, and offers an academically less challenging curriculum than academic secondary schools. The school is supposed to prepare students for further vocational training at the end of the compulsory schooling age. Students who intend to pursue an apprenticeship supplement it with a one year pre-vocational school before leaving full-time schooling at age 15. Alternatively, students can enter a full-time vocational school, either an intermediate vocational school, which intends to prepare students primarily for a profession, or an upper vocational school, which supplements training for a profession with the preparation for the university entrance exam.

Selection into the different types of secondary school depends on a combination of primary school grades and the recommendations by the primary school, a formal entrance exam, and parental choice. There are also rules based on grades and exams, which allow students to transit from lower secondary schools to the academic secondary schools. 
About 40 percent of a cohort complete an apprenticeship, mostly after leaving general secondary school. 23 percent leave school at 15 without any formal qualifications (Hauptschulabschluß) and start work as an unqualified laborer. Apprentices will receive training in a particular occupation in a firm. In addition, the apprentice will attend a part-time vocational school (Berufschule), either one or two days a week or in block courses at certain times during the year. The firm provides both the practical component of the training as well as on-the-job experience. The vocational school supplements the training by more theoretical components tailored to the chosen occupation, as well as providing further liberal arts education. In addition to learning at the firm and in vocational school, some training firms organize joint courses or send their apprentices to external training centers for certain aspects of the training. This happens more frequently in small firms, for example, because they lack certain machines, which are supposed to be part of the training curriculum.

The apprenticeship training is highly regulated. There are currently 275 apprenticeship occupations, with nationally legislated curricula. Each training firm has to satisfy certain requirements in order to be allowed to take on apprentices. In particular, there has to be a qualified trainer at the firm. The oversight of the training firms is done by the Apprenticeship Offices of the regional chambers of commerce. They also carry out the graduation exams for the apprentices. Apprentices obtain an allowance, negotiated in union contracts, which differs by occupation. The remuneration of apprentices starts out very low in the first year, and may rise up to about 80 percent of a skilled worker's wage in the last year.

Apprenticeships are not at all homogeneous, and the content and quality of training will vary greatly between occupations and training firms. Apprenticeships last between two and four years, with durations of three and three and a half years being the most common. The duration of the apprenticeship may be reduced if the apprentice has prior relevant skills or a higher level of schooling, like a Matura. About 10 percent of apprentices pursue combination apprenticeships in two related occupations at the same time (Doppellehren). Where the content of the trades overlaps substantially, these combination apprenticeships can be completed in a much shorter time span than two individual apprenticeships. Examples are vehicle mechanic/vehicle electrician, plumber for water and 
gas/plumber for central heating systems, or cook/waiter. Table 1 displays the distribution of contractual apprenticeship lengths.

The same occupation (say vehicle mechanic) may be learnt either in a small crafts firm, or in a large industrial enterprise. In the small firm, the training will be largely on-the-job, and apprentices are well integrated into the business activity of the firm. In the large firm, the first year of training may be spent entirely in an internal training workshop with full-time trainers. Afterwards, apprentices may rotate to different types of jobs within the firm.

Apprentices can obtain additional credentials after accumulating some experience in their chosen trade. Additional training and exams may lead to the master craftsman credential (Meister) or an equivalent qualification, which allows the degree holder to train apprentices and is often the prerequisite for self-employment in a certain profession.

The vocational training system in Austria encompasses a wide variety of occupations. An apprenticeship may be in a traditional crafts profession (baker, cook, mechanic, hair dresser), in administrative and clerical occupations, sales, or in technical professions (machinery electrician, chemical laboratory technician). Vocational training may lead to a qualification, which would be considered a fairly low skilled occupation in most countries (waiter or sales clerk). But it may also lead to an occupation, which would require at least some college education in other countries, particularly when it combines an apprenticeship with more advanced school based training (technician or middle manager).

Not all apprentices complete their apprenticeship. Some apprentices will leave their apprenticeship early for a variety of reasons. Many of them will continue their apprenticeship in another firm and/or occupation. About 18 percent of apprentices dropped out of the apprenticeship system completely in the 1980s. About one fifth of apprentices had two apprenticeship contracts, and one tenth had three or more (Schneeberger et al., no date).

Apprentices may also leave the apprenticeship without the resulting skilled worker credential because they fail the final examination. About 85 percent of exam entrants pass. The exam can be repeated 
after three months if the candidate was unsuccessful. Roughly 70 percent of failed candidates attempt the exam again within a year and about 75 percent of repeaters pass (Schneeberger et al., no date). This suggests that more than 90 percent of apprentices pass the final exam eventually.

\section{The Data}

We use employment records from the Austrian Social Security Administration. The data set includes the universe of private sector workers in Austria, including apprentices, covered by the social security system. It excludes public sector workers and the self-employed. This is a drawback, since about 10 percent of apprenticeship trained workers are self-employed, and self-employment is frequently a successful outcome for an apprentice. All the employment records can be linked to the establishment in which the worker is employed. The data set covers the years 1972 to 1998 but we only use records from 1975 onwards, because the employer level information is frequently inaccurate in the earlier years.

Each establishment has an employer social security number. Hence, an exit of an establishment in the data occurs when the employer identifier ceases to exist. However, some of these cases are not true firm exits, and (most of) the employees continue under a new identifier. If more than $70 \%$ of the employees continue under a new employer identification number we do not consider this a failure of the establishment. In some cases, the employer id may refer to the employees in multiple sites; in other cases, multiple plants in a single firm may have separate numbers. This is not a particular problem for us, but it may weaken our first stage relationship. Furthermore, we limit our analysis to the subsample of failing firms where the loss in employment in the six months before the quarter of the failure is less than 25 percent. Firms, which shed workers for a while before the eventual failure, will likely have different hiring practices than those who fail rather suddenly. Hence, we are more confident that apprentices hired relatively close to the failure of the firm are similar to those hired earlier in this more limited sample. We also limit the sample to small training firms with less than 10 employees. 
We identify firms who fail according to the definition above. We then begin by recording all workers who received some apprenticeship training in the data set, and who worked in one of these failing firms during some time in their career. We can then track at what time the failure occurred, after the worker first entered the firm. We only retain those individuals, whose firm fails within 16 quarters from the original entry date. This should include all apprentices who spent up to four years in the failing firm, and therefore up to the maximum length of an apprenticeship.

We only consider men in the analysis below. Wages are standardized daily wages, gross wages (up to maximum contribution basis for the social security system) divided by effective employment duration. Interruptions due to illness are not counted as employment. We neglect the problem of top-coding, because it is largely irrelevant for apprenticeship trained workers in their first years on the job.

\section{$4 \quad$ Empirical Framework}

The following is a simple framework to think about the behavior of apprentices. Let $L^{*}$ be the latent apprenticeship duration for a particular apprentice. An apprentice, who does not train at a failing firm will realize that duration, so that the actual duration of the apprenticeship is $L=L^{*}$. This may be completed in a single firm, or the apprentice may quit the original training firm and complete the apprenticeship elsewhere. Variation in $L^{*}$ combines the fact that different apprenticeship occupations require a different duration, as well as the fact that some apprentices quit early. $L^{*}$ is likely related to the ability and motivation of an apprentice, apart from the fact that individuals with different levels of $L^{*}$ will have accumulated different amounts of human capital.

We only consider failures in the first firm an apprentice joins. Let $K$ be the time from the entry of the apprentice into this firm until the firm fails. This is not necessarily the same as the time an apprentice spends in the failing firm. For example, the apprentice may leave the firm early, either because $L^{*}<$ $K$, or because the apprentice decides to complete the apprenticeship in another firm. The random variable $K$ will be independent of $L^{*}$ as long as the distribution of $L^{*}$ does not vary among the apprentices, who join the failing firm at different times before the failure. In other words, the last 
apprentices to join a failing firm have to have similar (observable and unobservable) characteristics as those who joined earlier. This is our key identifying assumption, and we will discuss the consequences of its violation below. It is important to note that the actual time spent by an apprentice in the failing firm is not independent of $L^{*}$. In order to see this, note that apprentices who actually stay in the failing firm for time $K$ will by definition have $L^{*} \geq K$, so that these apprentices now come from a truncated distribution of $L^{*}$

Apprentices in failed firms will realize a total apprenticeship duration $L=L(K)$. The realized length of the apprenticeship for an apprentice in a failed firm may be equal to $L^{*}$, it may be shorter, or it may be longer. An apprentice in a failing firm may leave and complete the apprenticeship elsewhere in the original time. However, it is plausible that apprentices, who leave their original training firm, may take longer than originally anticipated to complete their training, maybe because the change of firms necessitates a change in occupation. Alternatively, an apprentice, whose firm fails, may decide not to complete their training, although the apprentice would have completed it otherwise, i.e. $L(K)<L^{*}$.

Another important assumption of our approach is that $E(L(K))<E\left(L^{*}\right)$, i.e. being subject to the failure of the training firm on average reduces the completed training of the affected apprentices. This is similar to the existence of a first stage when estimating a system of equations by two stage least squares, and it can easily be verified in our data. If all or most apprentices affected by firm failures took as long or longer to complete their apprenticeship, as did those not affected, then there would be no useful variation in $L(K)$ for us to exploit. This assumption can be checked in our data since we observe $L=L^{*}$ among those apprentices whose firm fails after they completed their apprenticeship.

Finally, we want to estimate the relationship

$w_{i t}=\alpha+\beta L_{i}+x_{i t}{ }^{\prime} \gamma+\varepsilon_{i t}$

where $w_{i t}$ is the log wage for individual $i$ in year $t, x_{i t}$ are other covariates like age, and $\varepsilon_{i t}$ is an error term. The standard problem is that $L_{i}$ is related to $L_{i}^{*}$, which may be correlated with the error term. Hence, our approach is to instrument $L_{i}$ by $K_{i}$ in the sample of apprentices for whom $K_{i}$ is four years or less, i.e. who are potentially affected by the failure of their training firm. 
If the returns to training differ by individual, and/or by the stage of training, instrumental variables estimation will identify a local average treatment effect (Imbens and Angrist, 1994, Angrist and Imbens, 1995, and Angrist, Imbens and Rubin, 1996) for the individuals, whose behavior is affected by the firm failure (this group is often labeled “compliers”). For this interpretation to be correct, it is necessary that a monotonicity assumption holds. In our case, this means that a firm failure will not induce any individual to stay in the apprenticeship longer than they would have otherwise, or $L_{i} \leq L_{i}{ }^{*}$. We cannot rule out this possibility a priori, but we will discuss below whether there is evidence in our data that some individuals affected by firm failures have longer apprenticeship durations than the control group. We find that the fraction of individuals with particularly long durations is not higher among those affected by firm failures. This suggests that the monotonicity assumption seems to be satisfied in our data.

The group of compliers in our case, i.e. the apprentices for whom $L_{i}\left(K_{i}\right)<L_{i}{ }^{*}$, are likely to be individuals who are closer to the margin of dropping out of the apprenticeship anyway. In addition, we are not able to measure the return to the entire apprenticeship period, since everybody in the sample will have completed some part of training in the failing firm. Hence, we measure the return to partial apprenticeships, and in particular, the later years of the training period. There may be important non-linearities in the returns to apprenticeship training, for example due to credential effects of receiving the skilled worker certificate. In estimating equation (1) by instrumental variables we may mistakenly attribute these returns to the part of the apprenticeship period not completed by compliers.

The failure of a firm is not an event that will be completely unanticipated. It is well known from other studies that some workers tend to leave firms before the eventual failure (Hamermesh and Pfann, 2001). Some apprentices may leave their training firm because they expect the eventual failure of the firm, and the early leavers may not be selected from all apprentices at random. ${ }^{1}$ This is not directly a

\footnotetext{
${ }^{1}$ Such voluntary quits of apprentices may be very unlikely, unlike those of regular workers, because apprentices enjoy a very strict dismissal protection in their training contract.
} 
problem for our approach. This behavior may affect who is in the group of compliers, but it does not affect the interpretation of the results for that group.

Notice that the variation in $K$ comes from the fact that some apprentices joined a failing firm just before the failure, while others joined the firm at an earlier time. As noted above, our key identifying assumption is that apprentices joining within the last four years before the failure of the firm are comparable. For example, we will overestimate the returns to training if the quality of the apprentices, who are hired before the firm fails, is declining over time, because $K$ is positively correlated with worker quality in this case. In order to avoid this, we focus our analysis on a subsample of small training firms, who fail suddenly, and on apprentices who joined these firms one year before the failure or earlier. We expect our identifying assumption to be satisfied most easily in this subsample.

Another issue arises in estimating equation (1). We have seen that $L_{i}$ can be less than, equal to, or greater than the statutory length for an apprenticeship in the chosen occupation. It is common in the literature on returns to schooling to use the statutory length of an educational program. Typically, the endogenous regressor will be a variable like "highest grade completed.” If a student repeats a grade, and hence spends additional time in school to reach the same grade level, this additional time is not counted. Therefore, it seems sensible for our purposes not to count time spent beyond the statutory length of the apprenticeship. Unfortunately, we do not know what the statutory length is for a particular apprentice. Hence, we truncate $L_{i}$ at four years, the maximum length of an apprenticeship, and use the variable $\widetilde{L}_{i}=\min \left(L_{i}, 4\right)$ instead. $^{2}$

\section{$5 \quad$ Results}

Our results are exploiting the fact that some apprentices do not complete their apprenticeship, if it gets cut short by the failure of their firm. Failing firms are not a random sample of all firms. Table 2 shows that failing firms tend to be relatively small firms. Comparing columns (2) and (3) in the table

\footnotetext{
${ }^{2}$ Results do not change, if we use the original durations.
} 
to column (4) shows that firms who fail are smaller than the average training firm. Firm sizes for apprentices who are potentially affected by the firm failure (those joining the failing firms in the last 15 quarters before failure, column 2) are not very different than for those apprentices who work in firms, which fail after their apprenticeship. This is comforting, since it suggests that there is not much selection on the firm side on who hires apprentices until close to the time of failure. The biggest difference in the firm size distribution - as well as in other characteristics - is between apprentices who train in ever failing firms, and all apprentices. Only 43 percent of all apprentices train in firms with less than 20 employees compared to 59 percent in column (3). Other characteristics of the apprentices and apprenticeship firms are not strongly affected by our sample selection.

Table 3 presents evidence on the relationship between the potential duration of an apprentice in the failing firm, $K$, and the eventual length of the apprenticeship, $L$. Apprentices in our sample are grouped by the potential duration $K$, which is broken up into quarters. Each quarter of $K$ is a column in the table. In addition, means for everybody unaffected by the failure of their firm are summarized in the last column, labeled $16+$. The first five rows of the table tabulate the distribution of the length of the apprenticeship $L$, also in quarters, into five categories: $L<K, L=K, K<L<11$ quarters, $L=11$ to 13 quarters, $L$ is 14 quarters or longer. The second category, $L=K$, also includes all apprentices who left the firm within one quarter before failure. Exits from a failing firm rarely happen all at once, even in relatively small firms, and there seemed to be some piling up of individuals also in the category $L=K-1$. The third category, $K<L<11$ quarters, contains incomplete apprenticeships, but those that are longer than the duration in the failed firm. The fourth and fifth categories most likely contain completed apprenticeships. In fact, most apprenticeships ended after 11 to 13 quarters. Some apprenticeships last longer, or apprentices might have completed combination apprenticeships. Hence, individuals in the fifth category (14 or 15 quarters) may have legitimately taken as long to complete an apprenticeship, or they could have taken longer to complete their apprenticeship, for example because they had to switch training firms.

In considering table 3, start by looking at the distribution for those apprentices who joined a failing firm 16 or more quarters before failure. These apprentices were not affected by the firm failure during 
their apprenticeship (and are not used in our analysis below). 59 percent of them completed their apprenticeship within the standard time (11 to 13 quarters), and another 27 percent took longer than that. About 14 percent dropped out early, and most likely did not complete their apprenticeship.

Compare this distribution to those who joined the failing firm within 10 quarters or less to failure. Only around 48 to 55 percent of apprentices finish within 11 to 13 quarters in this group. 18-25 percent of apprentices take longer. There is no evidence that any apprentices affected by the firm failure during the apprenticeship took longer to complete their training than those not affected. This suggests that the monotonicity assumption is likely satisfied in our sample. On the flip side, about 20 to 30 percent of apprentices, who joined within 10 quarters to failure, left their apprenticeship early. About a third to a half of this attrition is in the quarter of failure ${ }^{3}$ or during the preceding quarter. This indicates that the failure of a firm induces some apprentices to leave the apprenticeship earlier than they would have otherwise. In fact, a lot of the additional incomplete apprenticeships seem to occur in the category where $L=K$, while there are almost another 5 to 10 percentage points of incomplete apprenticeships, where the apprentices drop out immediately after the failure of the firm. Hence, it seems like much of the dropping out induced by the failure of the firm seems to be coming from apprentices, who would have otherwise completed their apprenticeship.

Table 3 also displays the mean duration of the apprenticeship for each potential duration group. This is around 1000 days, slightly less than 3 years or 12 quarters. Apprentices, who joined the failing firms 10 quarters or more before failure have an average duration of more than 60 days more than those who joined closer to the failure. Since quarter to failure is our instrument, this gives a broad indication for the magnitude of the first stage effects.

Finally, the table also displays the number of observations in each quarter to failure group. This number is relatively small for the apprentices, who joined very close to failure. It becomes somewhat more stable for those apprentices joining before 5 quarters to failure, although the numbers are highest

\footnotetext{
${ }^{3}$ If one looks at a full cross-tab with quarterly information about quarters to failure and full duration of apprenticeship the quarter where $\mathrm{K}=\mathrm{L}$ is always the one with the highest cell percentage - apart from quarter 12 , which is the regular apprentice duration.
} 
for those joining 12 to 14 quarters to failure. This indicates that within the last year before the failure of the firm it may be clear that the failure is imminent or possible. Therefore, fewer apprentices are hired at that stage. This makes us worried that there may also be more selection among the group of apprentices who are still hired, or among the firms who still hire apprentices at that stage. Hence, we restrict the estimation sample to those apprentices who join the firm within 4 quarters to failure or more.

The relatively large number of apprentices, who have been in the failing firm for 12 to 14 quarters, might indicate that firms delay their exit behavior when they have an apprentice whose completion of the apprenticeship is imminent. This behavior by firms would only impact our instrumental variables estimates if it were correlated with unobserved determinants of the later earnings of the apprentices affected. ${ }^{4}$ However, it may also explain the relatively small number of apprentices who join 15 quarters to failure, and the fact that many of those who are observed tend to have relatively long apprenticeships. They may simply be apprentices in occupations with long apprenticeship duration.

Before proceeding, we merged the data on apprentices analyzed in the previous tables with the wages the apprentices earn later. There are up to 23 wage observations per apprentice, and the average number of observations per individual is 8.5 . The resulting panel data set has 47,881 observations. We account for the repeated observations on individuals in the following regressions by clustering standard errors.

We use two versions of the instrument. The first is a series of dummy variables for each quarter until the firm failure. Alternatively, we use a variable that is linear in the quarters until failure. Table 4 displays the corresponding first stage regressions. The other regressors in the model are age and age squared, a dummy for individuals without Austrian nationality, two dummies for starting the apprenticeship at 15 or $16^{5}$, and dummies for 22 survey years and eight regions. The length of the apprenticeship is measured in days, but is scaled in terms of years, so that our estimates are easily

\footnotetext{
${ }^{4}$ This would be the case, for example, if a firm decided to delay its exit when it has a particularly able apprentice but close early with a weak apprentice.

${ }^{5}$ The base category is age 17 . We excluded apprentices who started later because these might have had a mixed career already with some additional schooling or learning on-the-job in previous jobs.
} 
comparable to standard estimates of returns to education. The coefficients on potential duration bounce around and are often insignificant for the first five quarters. Between 9 and 12 quarters, the eventual length of the apprenticeship rises, and finally reaches a plateau of more than a quarter of a year in the range from 12 to 15 quarters. Not surprisingly, this pattern mirrors the one we already found in table 3 above.

The individual coefficients for quarters 10 and higher are highly significant. The F-statistic for the joint significance of the excluded dummy instruments is 89 . This suggests that the correlation of our instruments with the endogenous regressor is high enough that "weak instrument” problems are unlikely. Stock, Wright and Yogo (2002) consider first-stage F-values below 10 to 20 to be problematic. Our F-statistic clearly exceeds these thresholds. F-statistics with the linear instrument are even higher. Not surprisingly, when we estimate our models with LIML we obtain identical results to standard 2SLS.

Table 5 displays our main results for the full sample. Column (1) displays a relatively standard log wage regression on the length of the apprenticeship, controlling for actual labor market experience. The return to an additional year of apprenticeship is relatively small, 1.5 percent. This is a comparatively low estimate for Austria. Fersterer and Winter-Ebmer (2003a) find returns to apprenticeship training of around 15 percent for the entire apprenticeship. Given that an apprenticeship lasts on average about 3 years, this implies a return of about 5 percent a year. Our estimate here is only about a third of the previous estimate. We will return to the reasons for these low estimates in more detail below.

Column (2) displays OLS estimates where we replace labor market experience with age. Labor market experience is correlated with the length of the apprenticeship, and hence also endogenous. Controlling for age rather than experience is therefore common in many IV studies of the returns to 
schooling. The returns controlling for age are 2.7 percent now, slightly higher than those controlling for experience. ${ }^{6}$

The IV estimates are shown in columns (3) and (4). The estimate of 2.6 percent in column (3) using the dummy instruments is the same as the OLS estimate. The return is now less precisely estimated, and is not significantly different from zero. This imprecision is a natural consequence of the fact that IV estimation removes much of the variance in the length of the apprenticeship variable. The magnitude of our standard errors is similar as those in other IV studies of the returns to schooling, for example, Angrist and Krueger (1991). Column (4) shows the results using the linear version of the instrument. The point estimate is higher than in column (3) but this estimate is still not significantly different from the OLS estimate. Our IV estimates therefore suggest returns which are similar or somewhat larger than the OLS returns.

In summary, we find the wage returns to apprenticeship training are relatively low, although the IV estimates are as high as or higher than the OLS estimates. We have take care in selecting a sample where biases in the IV estimates due to a potential correlation of the instrument with apprentice quality are less likely. As a result, our estimates are restricted to a specific set of apprentices who trained in a narrow set of firms. Therefore, we do not think that the actual magnitude of the results is as interesting as the relative similarity of the OLS and IV estimates.

\section{Conclusion}

Apprentices and non-apprentices differ in many dimensions, and there is anecdotal evidence that better training providers tend to select the best school leavers. This suggests that standard OLS returns to apprenticeship training may be biased upward because of the selection. This is the first study to use an exogenous event to attempt to estimate returns, which are free from selection bias. Our focus on failed

\footnotetext{
${ }^{6}$ The standard specification of an earnings regression with age only includes age, age squared and schooling. Hence, the specification with potential labor market experience includes also schooling squared and an interaction of age and schooling. Returns to schooling are typically lower in the model controlling for age and age squared. Our specification also controls for age at the start of the apprenticeship. This means that there are additional interaction terms omitted when controlling for only age, rather than experience.
} 
firms necessarily implies that we are not able to estimate returns for a very representative sample of apprentices. Failed firms tend to be small, and they may be relatively poor training providers, particularly in the final phase of their existence. Moreover, we estimate returns to partially completed apprenticeships, which is different from the return to the entire apprenticeship. Hence, it might not be very surprising that we find relatively small returns to training in our setup.

Our main finding is that the estimated returns for apprentices affected by the firm failure are not very different from the OLS returns in the same sample. This suggests that selection in the drop-out behavior of apprentices is not particularly important. OLS returns to apprenticeship training have previously been found to be of similar magnitudes to other forms of education. From this we conclude that apprenticeship training does not seem to be superior to other forms of school based education, say in colleges or vocational schools.

Of course, there are some important limitations to our study. We only estimate wage returns. Some of the benefits of apprenticeship training may be in the form of higher employment probabilities and a reduced incidence of unemployment. Our data set is not well suited for analyzing this possibility since it only covers private sector employment. Hence, we cannot distinguish unemployment from employment in the public sector or self-employment. Apprenticeship training is often regarded as facilitating an easier school-to-work transition than is the case in purely school based education systems. This is difficult for us to ascertain, because all of our apprentices have had their ties to the original training firm severed because of the firm failure. This makes it difficult to draw conclusions about the attachment to the firm and the labor force from this particular group. In addition, we only look at wage returns for apprentices while they are still relatively young. Some of the returns to apprenticeship training may be accruing later on, for example, when some trained workers go on to become master craftsmen. 


\section{References}

Acemoglu, Daron and Jörn-Steffen Pischke (1998) "Why Do Firms Train? Theory and Evidence," Quarterly Journal of Economics 113, 79-119.

Angrist, Joshua D. and Guido W. Imbens (1995) "Two-Stage Least Squares Estimation of Average Causal Effects in Models with Variable Treatment Intensity," Journal of the American Statistical Association 90, 431-442.

Angrist, Joshua D., Guido W. Imbens, and Donald Rubin (1996) "Identification of Causal effects Using Instrumental Variables,” Journal of the American Statistical Association 91,

Angrist, Joshua D. and Alan B. Krueger (1991) "Does Compulsory School Attendance Affect Schooling and Earnings?” Quarterly Journal of Economics 106, 979-1014.

Becker, Sascha and Frank Siebern-Thomas (2004) "Supply of Schools, Educational Attainment and Earnings," mimeographed, University of Munich.

Büchtemann, Christoph F., Jürgen Schupp and Dana Soloff (1994) "From School to Work: Patterns in Germany and the United States,” in J. Schwarze, F. Buttler, and G.G. Wagner (eds.) Labour Market Dynamics in Present Day Germany. Frankfurt/Main: Campus, 112-141.

Fersterer, Josef and Rudolf Winter-Ebmer (2003a) “Are Austrian Returns to Education Falling Over Time?” Labour Economics 10, 73-89.

Fersterer, Josef and Rudolf Winter-Ebmer (2003b) "Smoking, Discount Rates and the Returns to Education” Economics of Education Review 22, 561-566.

Franz, Wolfgang, Joachim Inkmann, Winfried Pohlmeier, and Volker Zimmermann (2000) "Young and Out in Germany. On Youths' Chances of Labour Market Entrance in Germany,” in D. Blanchflower and R. Freeman (eds.) Youth Unemployment and Joblessness in Advanced Countries, Chicago and London: University of Chicago Press, 381-425.

Freeman, Richard and Ronald Schettkat (2001) "Skill Compression, Wage Differentials and Employment: Germany vs. the US,” Oxford Economic Papers 53, 582-603.

Hamermesh, Daniel and Gerard Pfann (2001) "Two Sided Learning, Worker Turnover and Displacement,” NBER Working Paper No. 8273.

Heckman, James (1993) “Assessing Clinton's Program on Job Training, Workfare, and Education in the Workplace,” NBER Working Paper 4428.

Ichino, Andrea and Rudolf Winter-Ebmer (1999) "Lower and Upper Bounds of Returns to Schooling: An Exercise in IV Estimation with Different Instruments," European Economic Review 43, 889-901.

Ichino, Andrea and Rudolf Winter-Ebmer (2004) “The Long Run Educational Costs of World War II,” Journal of Labor Economics 22, 57-86.

Imbens, Guido W. and Joshua D. Angrist (1994) "Identification and Estimation of Local Average Treatment Effects,” Econometrica 62, 467-475.

Krueger, Alan and Jörn-Steffen Pischke (1995) "A Comparison of East and West German Labor Markets Before and After Unification,” in R. Freeman and L. Katz (eds.) Differences and Changes in Wage Structures, Chicago: University of Chicago Press, 405-445.

Nickell, Stephen and Brian Bell (1996) "Changes in the Distribution of Wages and Unemployment in OECD Countries,” American Economic Review, 86, 302-08.

OECD (1998) “Getting Started, Settling in: The Transition from Education to the Labour Market” in OECD Employment Outlook, chapter 3. Paris: OECD, 81-122.

Ryan, Paul (2001) “The School-to-Work Transition: A Cross-National Perspective,” Journal of Economic Literature 39, 34-92. 
Schneeberger, Arthur et al. (no date) Informationen zur Lehrlingsausbildung 2000/2001, Institut für Bildungsforschung der Wirtschaft, Vienna.

Schneeberger, Arthur und Bernd Kastenhuber (1996) Anfänger- und Abschlußquoten in der Lehrlingsausbildung, Institut für Bildungsforschung der Wirtschaft, Schriftenreihe Nr. 102, Vienna

Soskice, David (1994) "Reconciling Markets and Institutions: The German Apprenticeship System," in L. M. Lynch, (ed.) Training and the private sector. International comparisons. NBER Series in Comparative Labor Markets, Chicago: University of Chicago Press, 25-60.

Steedman, Hilary (2001) “Benchmarking Apprenticeship: UK and Continental Europe Compared,” CEP Discussion Paper 513.

Stock, James H., Jonathan H. Wright, and Motohiro Yogo (2002) "A Survey of Weak Instruments and Weak Identification in Generalized Methods of Moments," Journal of Business and Economics Statistics 20, 518-529.

Winkelmann, Rainer (1996) “Training, Earnings and Mobility in Germany,” Konjunkturpolitik 42, 275-298. 
Table 1: Contractual Length of Apprenticeships, 1995 (in percent)

\begin{tabular}{lccc}
\hline \hline Length in years & $\begin{array}{c}\text { Single } \\
\text { Apprenticeships } \\
\text { (Einfachlehren) }\end{array}$ & $\begin{array}{c}\text { Double } \\
\text { Apprenticeships } \\
\text { (Doppellehren) }\end{array}$ & All \\
\hline 2 & 1.0 & 0.0 & 0.9 \\
2.5 & 0.2 & 0.0 & 0.1 \\
3 & 68.6 & 2.7 & 61.6 \\
3.5 & 29.3 & 0.0 & 26.2 \\
4 & 1.0 & 97.3 & 11.2 \\
\hline
\end{tabular}

Source: Schneeberger and Kastenhuber (1996), Table 16 
Table 2: Sample Characteristics (in percent)

\begin{tabular}{|c|c|c|c|c|}
\hline & \multicolumn{4}{|c|}{ Sample } \\
\hline & $\begin{array}{c}\text { Estimation } \\
\text { sample } \\
(1) \\
\end{array}$ & $\begin{array}{l}\text { joined failing } \\
\text { firm within } 15 \\
\text { quarters of } \\
\text { failure } \\
\text { (2) } \\
\end{array}$ & $\begin{array}{l}\text { joined failing } \\
\text { firm } 16 \text { or } \\
\text { more quarters } \\
\text { before failure } \\
\text { (3) }\end{array}$ & $\begin{array}{c}\text { all } \\
\text { apprentices } \\
(4) \\
\end{array}$ \\
\hline \multicolumn{5}{|l|}{ age at beginning of apprenticeship } \\
\hline 15 yrs. and younger & 55.1 & 57.2 & 59.8 & 59.7 \\
\hline 16 yrs. and older & 45.9 & 42.8 & 40.2 & 40.3 \\
\hline \multicolumn{5}{|l|}{ residence } \\
\hline town & 10.9 & 9.9 & 9.7 & 12.5 \\
\hline rural & 81.9 & 76.9 & 71.2 & 80.2 \\
\hline information missing & 7.2 & 13.2 & 19.1 & 7.3 \\
\hline \multicolumn{5}{|l|}{ nationality } \\
\hline Austrian & 64.7 & 67.1 & 65.6 & 56.1 \\
\hline other & 3.4 & 3.4 & 1.6 & 2.3 \\
\hline information missing & 31.9 & 29.5 & 32.8 & 41.5 \\
\hline \multicolumn{5}{|l|}{ firm size (beginning of apprenticeship) } \\
\hline $0-9$ employees & 100.0 & 42.4 & 40.2 & 24.4 \\
\hline 10-19 employees & & 18.5 & 18.7 & 18.5 \\
\hline 20-99 employees & & 26.6 & 26.1 & 29.8 \\
\hline 100 and more & & 12.5 & 15.0 & 27.3 \\
\hline \multicolumn{5}{|l|}{ industry classification } \\
\hline agriculture. mining. energy and water & 4.2 & 1.3 & 0.9 & 2.2 \\
\hline manufacturing & 44.6 & 36.5 & 34.0 & 35.2 \\
\hline construction & 18.2 & 24.9 & 22.7 & 24.8 \\
\hline wholesale and retail trade & 14.8 & 13.0 & 14.3 & 20.1 \\
\hline hotel and restaurant & 7.9 & 9.4 & 7.3 & 6.6 \\
\hline other private and public services & 3.7 & 3.1 & 2.9 & 4.9 \\
\hline information missing & 6.5 & 11.8 & 17.9 & 6.2 \\
\hline sample size & 5,661 & 23,893 & 103,201 & 676,368 \\
\hline
\end{tabular}

Notes: Estimation sample consists of apprentices who joined failing firms in quarters 4 to 15 before failure, and employment at the firm declined by less than 25 percent in the last two quarters before the firm exits. Sample in column (2) includes all apprentices joining a failing firm within 15 quarters of failure. Sample in column (3) includes apprentices joining a failing firm 16 or more quarters before failure. Sample in column (4) includes apprentices in all firms without restriction. 
Table 3: Length of Apprenticeships by Potential Duration in Failed Firms

\begin{tabular}{|c|c|c|c|c|c|c|c|c|c|c|c|c|c|c|c|c|}
\hline \multirow{2}{*}{$\begin{array}{l}\text { Eventual length of } \\
\text { Apprenticeship }\end{array}$} & \multicolumn{16}{|c|}{ quarters to failure } \\
\hline & 1 & 2 & 3 & 4 & 5 & 6 & 7 & 8 & 9 & 10 & 11 & 12 & 13 & 14 & 15 & $16+$ \\
\hline $\begin{array}{l}\text { Shorter than time to failure } \\
(L<K)\end{array}$ & 0.0 & 0.3 & 0.7 & 1.8 & 6.5 & 8.0 & 9.7 & 10.1 & 16.6 & 9.1 & 14.8 & 12.0 & 15.3 & 12.6 & 19.7 & 14.2 \\
\hline $\begin{array}{l}\text { Within one quarter of } \\
\text { failure }(L=K)\end{array}$ & 10.1 & 10.4 & 11.5 & 14.2 & 11.6 & 8.2 & 12.5 & 14.1 & 10.9 & 16.3 & 5.6 & 0.0 & 0.0 & 0.0 & 0.0 & 0.0 \\
\hline $\begin{array}{l}\text { Longer than failure but } \\
\text { incomplete }(K<L<11)\end{array}$ & 11.7 & 9.1 & 9.5 & 12.4 & 8.8 & 7.5 & 8.6 & 3.7 & 4.0 & 0.0 & 0.0 & 0.0 & 0.0 & 0.0 & 0.0 & 0.0 \\
\hline Complete (11 - 13 quarters) & 58.9 & 57.4 & 58.1 & 48.7 & 53.8 & 56.1 & 48.4 & 51.0 & 50.7 & 48.8 & 56.1 & 74.4 & 70.2 & 61.6 & 50.7 & 58.9 \\
\hline Longer & 19.3 & 22.8 & 20.3 & 23.0 & 19.3 & 20.2 & 20.8 & 21.1 & 17.8 & 25.8 & 23.5 & 13.6 & 14.5 & 25.8 & 29.7 & 27.0 \\
\hline $\begin{array}{l}\text { Mean duration of } \\
\text { apprenticeship (days) }\end{array}$ & 979 & 999 & 994 & 973 & 971 & 995 & 978 & 1,003 & 976 & 1,054 & 1,028 & 1,063 & 1,050 & 1,076 & 1,061 & 1,078 \\
\hline No. of observations & 195 & 298 & 148 & 226 & 398 & 415 & 279 & 298 & 477 & 559 & 392 & 594 & 731 & 834 & 458 & 32,682 \\
\hline
\end{tabular}


Table 4: First Stage Regressions for Length of Apprenticeship in Years

(1)

(2)

Potential duration in failing firm:

- 5 quarters

0.035

(0.005)

- 6 quarters

0.128

- 7 quarters

$(0.044)^{* *}$

0.099

$(0.050)^{*}$

- 8 quarters

0.050

(0.046)

- 9 quarters

0.077

(0.044)

- 10 quarters

0.206

$(0.042)^{* *}$

- 11 quarters

0.253

- 12 quarters

$(0.043)^{* *}$

0.308

$(0.041)^{* *}$

- 13 quarters

0.260

- 14 quarters

$(0.041)^{* *}$

0.315

- 15 quarters

$(0.040)^{* *}$

0.283

$(0.043)^{* *}$

Potential duration in failing firm

\section{R-squared}

0.13

88.64

$(0.002)^{* *}$

F-statistic for joint significance of excluded

795.51

instruments

Notes: Number of observations is 47,881. Regressions also contain a constant, dummies for the survey year and region,age, age squared, a dummy for foreigners, and two dummies for the age at the start of the apprenticship. Robust standard errors in parentheses are corrected for clustering at the level of the individual.

* significant at 5\%; ** significant at $1 \%$ 
Table 5: Wage Returns to Length of Apprenticeship Training

\begin{tabular}{lcccc}
\hline \hline & OLS & OLS & IV & IV \\
& $(1)$ & $(2)$ & $(3)$ & $(4)$ \\
\hline Length of apprenticeship & 0.015 & 0.027 & 0.026 & 0.041 \\
in years & $(0.002)^{* *}$ & $(0.002)^{* *}$ & $(0.016)$ & $(0.018)^{* *}$ \\
Experience & 0.062 & & & \\
& $(0.002)^{* *}$ & & & \\
Experience squared & -0.002 & & & \\
& $(0.001)^{* *}$ & & & \\
Age & & 0.109 & 0.109 & 0.105 \\
& & $(0.004)^{* *}$ & $(0.005)^{* *}$ & $(0.005)^{* *}$ \\
Age squared & -0.002 & -0.002 & -0.002 \\
& & $(0.001)^{* *}$ & $(0.001)^{* *}$ & $(0.001)^{* *}$ \\
Foreigner & -0.005 & -0.014 & -0.014 & -0.012 \\
& $(0.012)$ & $(0.013)$ & $(0.013)$ & $(0.013)$ \\
Age when starting & -0.025 & -0.002 & -0.001 & -0.011 \\
apprenticeship is 15 & $(0.007)^{* *}$ & $(0.007)$ & $(0.013)$ & $(0.013)$ \\
Age when starting & -0.026 & -0.027 & -0.027 & -0.035 \\
apprenticeship is 16 & $(0.007)^{* *}$ & $(0.007)^{* *}$ & $(0.011)^{* *}$ & $(0.012)^{* *}$ \\
\hline & & & 11 dummies & Linear variable \\
Instruments & --- & --- & for potential & for potential \\
& & & duration in & duration in \\
& & failing firm & failing firm \\
\hline $\mathrm{R}^{2}$ & 0.52 & 0.51 & --- & -- \\
\hline
\end{tabular}

Notes: Number of observations is 47,881. Regressions also contain a constant, dummies for the survey year and region. Robust standard errors in parentheses are corrected for clustering at the level of the individual.

* significant at $5 \%$; ** significant at $1 \%$ 
Figure 1:

The Austrian Education System

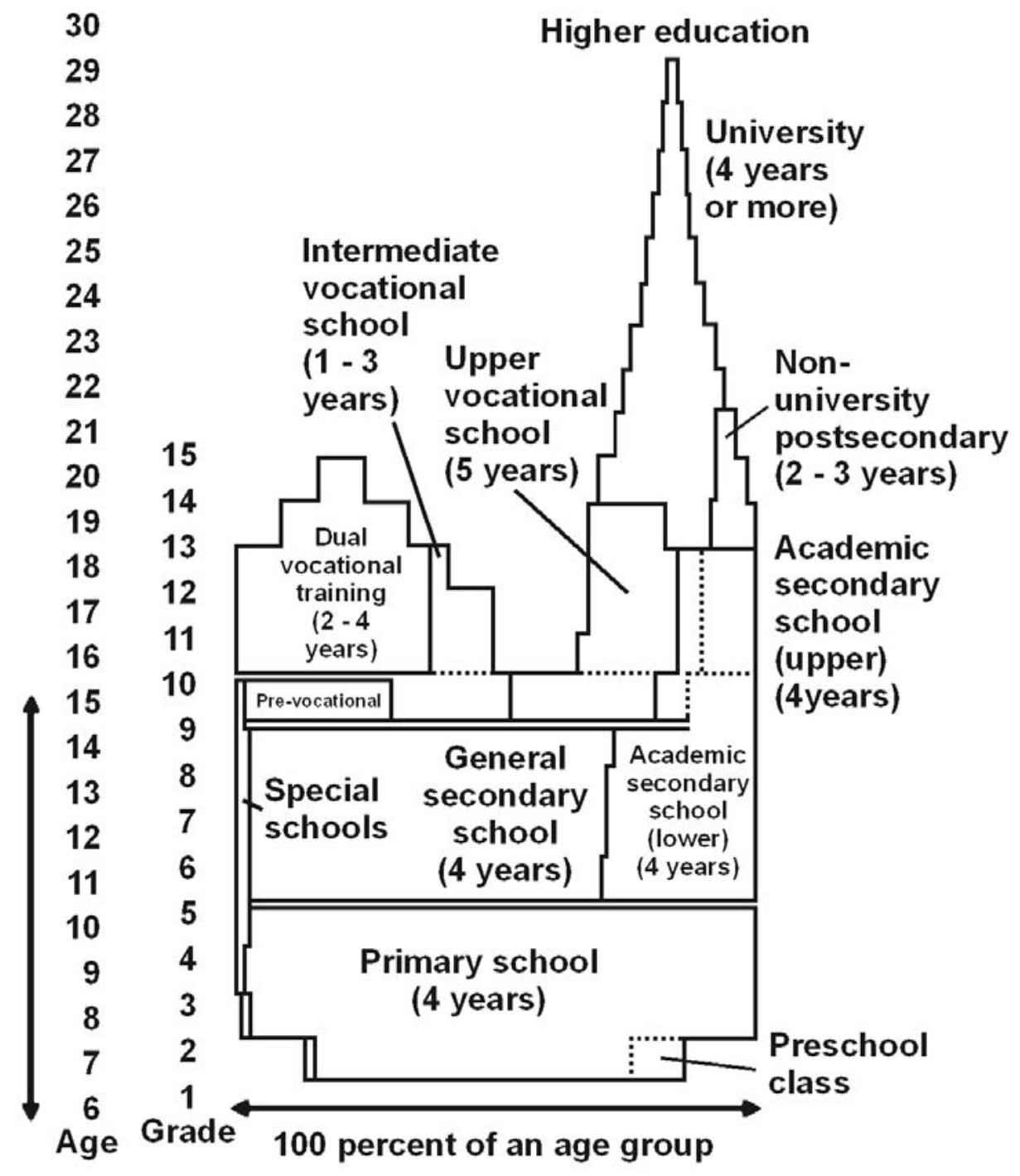

